\title{
土木学会論文報告集
}

第208号・1972 年 12 月

\section{拘束をうけるはりの弾性および非弾性横倒れ座屈解析 \\ AN ANALYSIS OF ELASTIC AND INELASTIC LATERAL BUCKLING OF RESTRAINED BEAMS}

\section{1. 緒言}

はりの横倒れ座屈に関する研究は非常に古くから多く の研究者によって，理論的，実験的になされてきた。こ れに関する研究は弾性域のみならず, 非弾性域にまで拡 張され, 多くの研究成果が発表され, 構造物の設計規準 にとり入れられている。

しかし，これまでの研究は，比較的単純な荷重条件お よび支持条件に対するもので，実際の構造物に作用する ような複雑な荷重条件や境界条件あるいは各種の拘束条 件を有するはり構造に適用するには, かなりの困難さが 認められた。

このような観点から，福本・久保 ${ }^{1), 2)}$ は等曲げを受け る横構および対傾構で結ばれた 2 本の桁の横倒れ座屈に 関する理論的・実験的研究を行なっている。理論的計算 においてはエネルギー法を用いているが，作用荷重が等 曲げに対するもので, 外力が簡単化されて取り扱われて いる。また, 吉田・西田 ${ }^{3}$ はスパンの中間でねじりが拘 束されている単純ばりに 2 点集中荷重を作用させたとき の横倒れ座屈強度の計算をエネルギー法を用いて計算し ている。Schmidt, L.C. ${ }^{4)}$ は単純ばりに集中荷重が作用 し，はりの両支点と荷重点にねじりおよび横たわみに対 して拘束ばねのあるはりの横倒れ座屈強度を, また, Taylor, A.C. and Ojalvo, M.O.5) は, はりにそって 連続的に分布するねじり拘束ばねおよび集中拘束ばねを 有するはりの横倒れ座屈強度の検討を行なっている。 Hartman, A.J. ${ }^{6)}$ はねじり拘束ばねおよび横変位の拘束 ばねを有する単純ばり，2 径間および 3 径間連続ばりに 1 個の集中荷重が作用する場合について階差法を用いて 横倒れ座屈強度を計算し, Trahair, N.S. ${ }^{7)}$ は Hartman, A.J. が用いたモデルを用いて実験的検討を行なってい

* 正会員 工博 金沢大学助教授 工学部土木工学科

** 正会員 工修 千葉県水道局技師

\author{
吉田 博*. 井本芳 宏** \\ By Hiroshi Yoshida and Yoshihiro Imoto
}

る。また, Powell, G. and Klinger, R. ${ }^{8)}$ はマトリック ス剛性法を用いて各種の拘束があるはりの横倒れ座屈強 度の計算を行ない, Trahair, N.S. の実験結果との比 較を行なっている。

一方, 通常の構造物のはりは, 断面の 1 部が塑性域に 入った非弾性域で座屈がおこり, 構造物の塑性設計の立 場からは，はりの非弾性横倒れ座屈に対する検討が要求 されてきた。

非弾性横倒れ座屈に関する研究は比較的少なく, これ に関する初期の研究は, 文献 9) に解説されている。 Galambos, T.V. ${ }^{10)}$ は H 形鋼ばりの非弾性横倒れ座屈 強度は, 形鋼の製作の過程で断面に導入される残留応力 に大きく影響されることを指適し，等曲げを受けるH形 鋼ばりの非弾性横倒れ座屈の設計公式を提案している。 この研究はさらに, 曲げのみならず軸方向力を受けるは り一柱の曲げねじれ座屈へと展開している ${ }^{11), 12) 。 は り ~}$ の非弾性横倒れ座屈の最近の研究としては, スパン中間 でねじりおよび横変位に対する拘束ばねを有する長方形 断面ばりの研究があり ${ }^{13)}$ ，等曲げおよび集中荷重が作用 する場合について論ぜられ，また，横構および対傾構で 結ばれた並列桁に関する前述の文献 1) がある。

本研究においては, 実際の構造物に見られるような, 単純ばりおよび連続ばりの支承およびスパン中間におい て任意の拘束を受ける 1 軸対称断面ばりに, 任意の荷重 が作用する場合の弾塑性横倒れ座屈強度を計算するた め, 比較的簡単な計算であらゆる場合に応用が容易であ る伝達マトリックス法を用いた。横倒れ座屈解析への伝 達マトリックス法の応用は, 文献 14)によってなされて おり, 曲げモーメントおよび軸方向力を考慮した一般性 のある微分方程式を用い，その方程式を直接解くことは せず, Runge-Kutter 法により近似的に伝達マトリック スを導いている。この論文においては, 変断面ばりおよ び斜めハンガーを有するはりを解析の対象としている。 また, 曲げねじりの影響を無視してアーチの面外座屈を 
解析した文献 15）がある。

本研究においては, 1 軸対称断面に曲げのみが作用す る場合についての格間伝達マトリックスを陽な形で導 き，任意の拘束条件に対する格点伝達マトリックスを用 いて, 任意の境界条件に対する弾塑性横倒れ座屈強度の 計算法を示し, 各種の拘束をらける 2 径間連続ばりの弾 性横倒れ座屈強度の計算例および各種荷重条件および境 界条件のもとでの単純ばりの非弹性横倒れ座屈強度につ いて検討を加えた。

\section{2. 解析に用いた仮定}

1）はりは少なくとも 1 軸対称断面で, 横倒れ座屈に 対しては初期変形はないものとする。

2）横断面形は座屈後も元の断面形状を保つものとす る。

3）鉛直変位は小さいものとする。

4）応力ーひずみ関係は完全弹塑性体のものを用い る。

5）はり断面の残留応力分布は, 圧延成形断面および 溶接組立断面の残留応力分布を 理想化した図一1 (a) お よび (b) のものを用いる。

6）はりの非弹性域における曲げ岡性および曲げねじ れ剛性は弾性域のみを有効とする Tangent Modulus Theory によるものとし，㸚じり剛性は全断面を有効と する塑性流れ理論によるものとする。

7）はりの分割要素間では曲げモーメントは一定であ り, 荷重および各種の拘束ばねは, はりの分割節点に作 用するものとする。

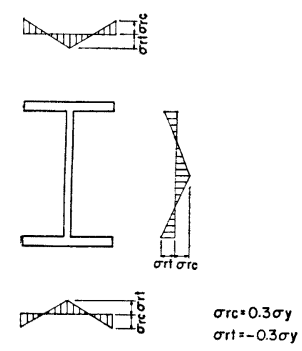

(a) PATTERN(A)
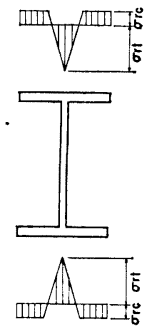

(b) PATTERN (B)

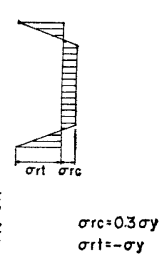

$\sigma r c=0.3 \sigma y$
$\sigma r t=-\sigma y$

図一1 理想化した残留応力分布

\section{3. 伝達マトリックスの誘導}

\section{（1）基礎方程式}

図一2 に示すはり要素 $i$ に扔いて, 断面の重心を通り 部材軸方向に $z$ 軸を, 部材面内で $z$ 軸に直角な主軸方向 を $x$ および $y$ 軸とする。部材要素 $i$ の材端 $i-1, i$ に

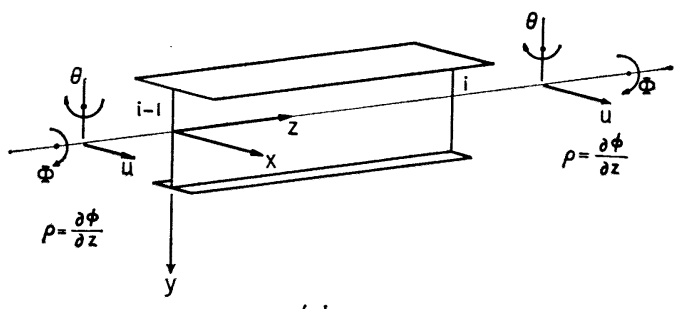

(a)

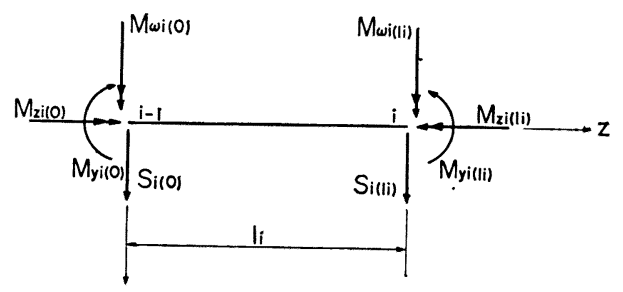

(b)

図一2 部材要菜 $i$ の座標軸, 断面力および变形

おける断面力（せん断力, 曲げモーメント, ねじりモ一 メント, バイモーメント) と変形量（たわみ,たわみ角, ねじり角，ねじり率）の図一2(a) および (b) に示す方 向をそれぞれ正の方向とする。部材要素 $i$ の曲げ剛性 $E I_{y}$ ，ねじり剛性 $G K_{T}$ および曲げねじれ剛性 $E I_{\omega}$ は それぞれ一定であるとすれば, $y-z$ 面内で等しい曲げを 受ける $y$ 軸が対称軸である 1 軸対称断面部材に対するは りの横倒れ座屈の微分方程式は ${ }^{17), 18)}$,

$$
\begin{aligned}
& E I_{y} \frac{d^{4} u}{d z^{4}}+M_{0} \frac{d^{2} \phi}{d z^{2}}=0 \\
& E I_{\omega} \frac{d^{4} \phi}{d z^{2}}-\left(G K_{T}+\bar{K}\right) \frac{d^{2} \phi}{d z^{2}}+M_{0} \frac{d^{2} u}{d z^{2}}=0
\end{aligned}
$$

によって表わされる。ここに，uおよび $\phi$ は横変位お よびねじれ角で，

$$
\bar{K}=\int_{A} \sigma a^{2} d A
$$

であり， $\sigma$ は断面内の要素の応力, $a$ はせん断中心から この要素までの距離を示す。

式（1）および（2）の連立微分方程式の一般解は,

$$
\begin{aligned}
u= & -\frac{M_{0}}{E I_{y}}\left(\frac{K_{1}}{\alpha_{1}{ }^{2}} \sinh \alpha_{1} z+\frac{K_{2}}{\alpha_{1}{ }^{2}} \cosh \alpha_{1} z\right. \\
& \left.-\frac{K_{3}}{\alpha_{2}{ }^{2}} \sin \alpha_{2} z-\frac{K_{4}}{\alpha_{2}{ }^{2}} \cos \alpha_{2} z\right) \\
& +\frac{1}{E I_{y}}\left(K_{5} z+K_{6}\right) \ldots \ldots \ldots \ldots \ldots \ldots \ldots \ldots \ldots \ldots \ldots \ldots . \cdots
\end{aligned}
$$$$
\phi=K_{1} \sinh \alpha_{1} z+K_{2} \cosh \alpha_{1} z+K_{3} \sin \alpha_{2} z
$$$$
+K_{4} \cos \alpha_{2} z-\frac{K_{7}}{M_{0}} z-\frac{K_{8}}{M_{0}}
$$ 
にて与えられる。ここに，

$$
\begin{aligned}
& \lambda_{1}=\frac{G K_{T}+\bar{K}}{E I_{\omega}}, \quad \lambda_{2}=\frac{M_{0}{ }^{2}}{E^{2} I_{y} I_{\omega}}, \\
& \alpha_{1}=\sqrt{\frac{\lambda_{1}+\sqrt{\lambda_{1}^{2}+4 \lambda_{2}}}{2}}, \quad \alpha_{2}=\sqrt{\frac{-\lambda_{1}+\sqrt{\lambda_{1}{ }^{2}+4 \lambda_{2}}}{2}}
\end{aligned}
$$

であり, $K_{1} \cdots K_{8}$ は積分定数である。これより残りの変 形量および部材の断面力は,

$$
\begin{aligned}
\theta= & u^{\prime} \\
= & -\frac{M_{0}}{E I_{y}}\left(\frac{K_{1}}{\alpha_{1}} \cosh \alpha_{1} z+\frac{K_{2}}{\alpha_{1}} \sinh \alpha_{1} z\right. \\
& \left.-\frac{K_{3}}{\alpha_{2}} \cos \alpha_{2} z+\frac{K_{4}}{\alpha_{2}} \sin \alpha_{2} z\right)+\frac{K_{5}}{E I_{y}} \cdots(6) \\
\rho= & \phi^{\prime} \\
= & \alpha_{1} K_{1} \cosh \alpha_{1} z+\alpha_{1} K_{2} \sinh \alpha_{1} z \\
& +\alpha_{2} K_{3} \cos \alpha_{2} z-\alpha_{2} K_{4} \sin \alpha_{2} z-\frac{K_{7}}{M_{0}} \cdots(7) \\
S= & -E I_{y} u^{\prime \prime \prime} \\
= & M_{0}\left(\alpha_{1} K_{1} \cosh \alpha_{1} z+\alpha_{1} K_{2} \sinh \alpha_{1} z\right. \\
& \left.+\alpha_{2} K_{3} \cos \alpha_{2} z-\alpha_{2} K_{4} \sin \alpha_{2} z\right) \cdots \cdots \cdots \cdots(8) \\
M_{\eta}= & -E I_{y} u^{\prime \prime} \\
= & M_{0}\left(K_{1} \sinh \alpha_{1} z+K_{2} \cosh \alpha_{1} z\right. \\
& \left.+K_{3} \sin \alpha_{2} z+K_{4} \cos \alpha_{2} z\right) \cdots \cdots \cdots \cdots \cdots(9) \\
M_{z}= & G K_{T} \phi^{\prime}-E I_{\omega} \phi^{\prime \prime \prime} \\
= & \left(G K_{T}-E I_{\omega} \alpha_{1}{ }^{2}\right) \alpha_{1} K_{1} \cosh \alpha_{1} z \\
& +\left(G K_{T}-E I_{\omega} \alpha_{1}{ }^{2}\right) \alpha_{1} K_{2} \sinh \alpha_{1} z \\
& +\left(G K_{T}+E I_{\omega} \alpha_{2}{ }^{2}\right) \alpha_{2} K_{3} \cos \alpha_{2} z \\
& -\left(G K_{T}+E I_{\omega} \alpha_{2}{ }^{2}\right) \alpha_{2} K_{4} \sin \alpha_{2} z-G K_{T} K_{7} / M_{0}
\end{aligned}
$$

$$
\begin{aligned}
M_{\omega}= & -E I_{\omega} \phi^{\prime \prime} \\
= & -E I_{\omega}\left(\alpha_{1}{ }^{2} K_{1} \sinh \alpha_{1} z+\alpha_{1}{ }^{2} K_{2} \cosh \alpha_{1} z\right. \\
& \left.-\alpha_{2}{ }^{2} K_{3} \sin \alpha_{2} z-\alpha_{2}{ }^{2} K_{4} \cos \alpha_{2} z\right) \cdots \cdots \cdots
\end{aligned}
$$

によって表わされる。

\section{（2）格間伝達マトリックス}

式 (4)より式 (11) までをマトリックス形式で書き表 わすと,

$$
\boldsymbol{Z}(\boldsymbol{z})=B(z) \cdot \boldsymbol{a}
$$

となる。ここに, $\boldsymbol{Z}(z)$ および $\boldsymbol{a}$ は,

$$
Z^{T}(z)=\left\{u \theta \phi \rho S M_{\eta} M_{z} M_{\omega}\right\}
$$

で表わされる $z=z$ での状態量ベクトルおよび

$$
\boldsymbol{a}=\left\{K_{1} K_{2} K_{3} K_{4} K_{5} K_{6} K_{7} K_{8}\right\}
$$

で表わされる定数べクトルであり， $B(z)$ は 8 行 8 列の マトリックスである。

これより, はり要素 $i$ の左端と右端の状態量を関係 うける格間伝達マトリックスは，

$$
F_{i}=B(l) \cdot B(0)^{-1}
$$

にて表わされる ${ }^{21)} 8$ 行 8 列のマトリックスである（付録 参照)。

\section{（3）格点伝達マトリックス}

a) 弾性拘束のある場合の格点伝達マトリックス

図一3に示すように横変位に対する拘束ばね定数を $K_{u i}$, はりの横変位のたわみ角に対する拘束ばね定数を $K_{0 i}$ ， はりのねじれに対する拘束ばね定数を $K_{b i}$, はり の断面のそりに対する拘束ばね定数を $K_{\omega i}$ とする。こ れら 4 種の拘束ばねは点 $i に$ 取り付けられており, 特 に,たわみ角および横変位に対する拘束ばねはせん断中 心に取り付けられているものとする。格点 $i$ の左端と 右端の状態量を結びつける格点伝達マトリックスは,

$$
P_{i}=\left[\begin{array}{cccccccc}
1 & 0 & 0 & 0 & 0 & 0 & 0 & 0 \\
0 & 1 & 0 & 0 & 0 & 0 & 0 & 0 \\
0 & 0 & 1 & 0 & 0 & 0 & 0 & 0 \\
0 & 0 & 0 & 1 & 0 & 0 & 0 & 0 \\
-K_{u i} & 0 & 0 & 0 & 1 & 0 & 0 & 0 \\
0 & -K_{0 i} & 0 & 0 & 0 & 1 & 0 & 0 \\
0 & 0 & -K_{b i} & 0 & 0 & 0 & 1 & 0 \\
0 & 0 & 0 & -K_{\omega i} & 0 & 0 & 0 & 1
\end{array}\right]
$$

と表わすことができる。
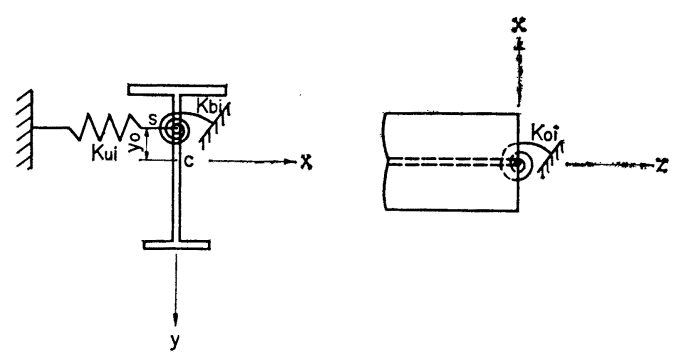

図一3 格点 $i$ の弾性拘束

b）剛支持されている点での格点伝達マトリックス ばねを介することなく，直接に支持されている支点に おいては, 弾性支承の伝達マトリックスのばね定数を無 限大とすることは, 数值計算上好ましくはないので, 剛 支持の条件から線形関係式を修正する必要がある ${ }^{20)}$ 。

たとえば, 格点 $n$ が横変位およびねじれに対して剛支 持されている場合の条件式は,

$$
u_{n}=\phi_{n}=0
$$

である。連続ばりの左端の自由度から成る初期ベクトル $A_{1}{ }^{L}$ を格間 $n$ の右端まで伝達すると次の式を得る。

$$
\boldsymbol{V}_{n}{ }^{R}=F_{n} P_{n-1} \cdots P_{1} F_{1} R \boldsymbol{A}_{1}{ }^{L}
$$

ここに, $F_{1}, \cdots, F_{n}$ は格間 $1, \cdots, n$ の格間伝達マト リックスであり, $P_{1}, \cdots, P_{n-1}$ は格点 $1, \cdots, n-1$ の格 点伝達マトリックスであり, $V_{n}{ }^{R}$ は格点 $n$ の左端の状 態量ベクトル， $R$ は連続ばりの左端の境界マトリックス である。いま，左端が横曲げおよびねじれに対して単純 支持である場合, 式（14）は次のように表わされる。 


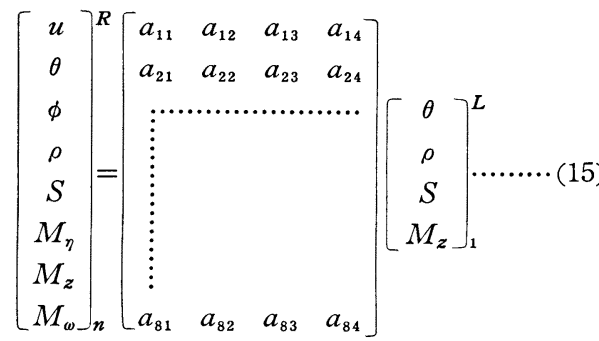

横変位およびねじれに対して剛支持されている格点 $n$ では, せん断力 $S$ とねじりモーメント $M_{z}$ が支点反力 によって不連続となる。この剛支点での支点反力（飛躍 量) $S^{\prime}$ および $M_{z}^{\prime}$ を新しい未知量とし, 格点 $n$ が横 変位およびねじれに対して剛支持されているといら条件 を用いて, 格点 $n$ の右端の状態量ベクトル $\boldsymbol{V}_{n+1}{ }^{L}$ は,

$\left[\begin{array}{c}u \\ \theta \\ \phi \\ \rho \\ S \\ M_{\eta} \\ M_{z} \\ M_{\omega}\end{array}\right]_{n+1}^{L}\left[\begin{array}{cccc}a_{11}+a_{13} b_{11}+a_{14} b_{21} & a_{12}+a_{13} b_{12}+a_{14} b_{22} & 0 & 0 \\ \vdots & \vdots & 0 & 0 \\ \vdots & \vdots & 0 & 0 \\ \vdots & \vdots & 0 & 0 \\ \vdots & \vdots & 1 & 0 \\ \vdots & \vdots & 0 & 0 \\ \vdots & \vdots & 0 & 1 \\ a_{81}+a_{83} b_{11}+a_{84} b_{21} & a_{82}+a_{83} b_{21}+a_{84} b_{22} & 0 & 0\end{array}\right]$ $\cdot\left[\begin{array}{c}\theta_{1}{ }^{L} \\ \rho_{1}{ }^{L} \\ S^{\prime} \\ M_{z^{\prime}}{ }^{\prime}\end{array}\right]$.

と表わすことができる。ただし，

$$
\begin{array}{ll}
b_{11}=-\frac{a_{11} a_{34}-a_{31} a_{14}}{a_{13} a_{34}-a_{33} a_{14}}, & b_{12}=-\frac{a_{12} a_{34}-a_{32} a_{14}}{a_{13} a_{34}-a_{33} a_{14}} \\
b_{21}=\frac{a_{11} a_{33}-a_{31} a_{13}}{a_{13} a_{34}-a_{33} a_{13}}, \quad b_{22}=\frac{a_{12} a_{33}-a_{32} a_{13}}{a_{13} a_{34}-a_{14} a_{33}}
\end{array}
$$

c）種々の拘束状態に対する格点伝達マトリックス

表一1 は実際の構造物において考えられる種々の拘束 状態に対する格点伝達マトリックスの求め方を例示した ものである。

d）荷重作用位置の影響

一般に荷重ははりのせん断中心に作用することなく， せん断中心より $h_{0}$ だけ隔てた対称軸上に作用する。こ の場合，はりの回転に伴うねじれモーメントが付加され る。図一4 はこの状態を示したもので, 㸚じり角 $d \phi に$
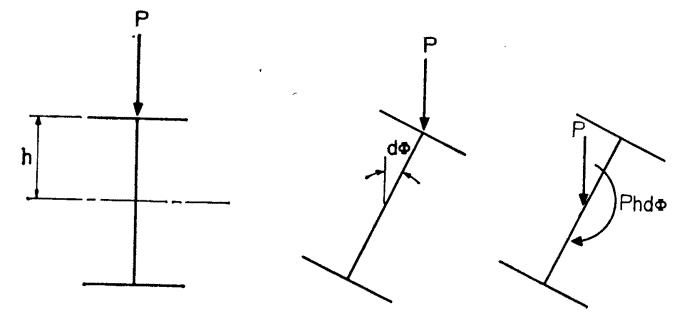

図一4 荷重作用点による付加ねじりモーメント
表一1 種々の拘束状態に対する格点伝達マトリックスの例

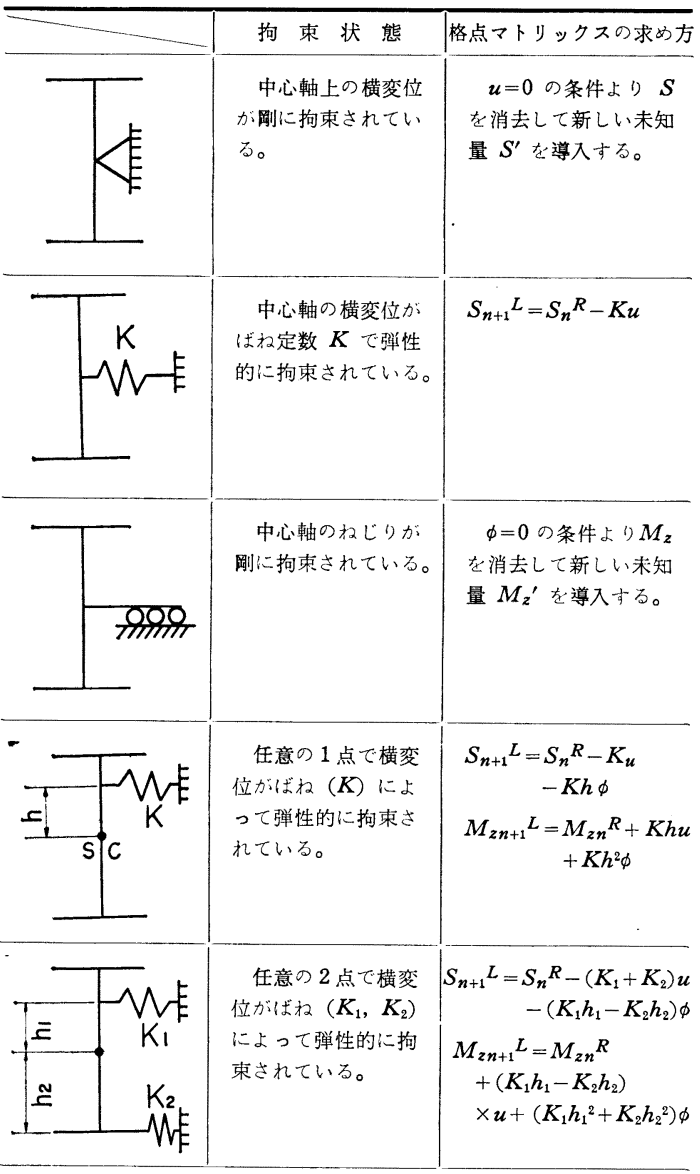

対して付加されるねじりモーメント $d M_{z}$ は, $d M_{z}=-P h_{0} d \phi$

となる。ここに, $P$ は格点に作用する荷重である。これ より，Pho の大きさの㱛じりに対する拘束ばねが格点に あると考えて，式 (13) に扔いて， $K_{b i}=P h_{0}$ とおけば よい。ただし， $h_{0}$ はせん断中心より下方を正とする。

\section{4. はりの境界条件式}

\section{（1）弾性ばねのない支点の境界条件式}

表一2 に種々の境界条件とそれに対応する左端の自由 度が示されている。境界条件を考虑した左端の状態量 $V_{1}^{L}$ は,

$$
\boldsymbol{V}_{1}{ }^{L}=R \boldsymbol{A}_{1}{ }^{L}
$$

にて表わされる ${ }^{20)}$ 。ここに， $R$ は左端の境界マトリッ クスであり， $\boldsymbol{A}_{1}{ }^{L}$ は左端の自由度から成る初期ベクトル である。

また, 右端の境界条件式は, 右端の状態量ベクトル $V_{n}{ }^{R}$ に右端の境界マトリックス $R^{\prime}$ を前掛けして, 
表一2 はり端における境界条件の例

\begin{tabular}{|c|c|c|c|c|}
\hline & (a) & (b) & (c) & (d) \\
\hline 放じりに対する拘束状態 & $X-X$ & $1-1$ & 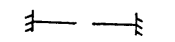 & $-\longrightarrow$ \\
\hline 横変位に対する拘束状態 & $\Delta-\Delta$ & $\Delta-\lambda$ & $1-1$ & $-\longrightarrow$ \\
\hline そりに対する拘束状態 & $-\longrightarrow$ & $-\longrightarrow$ & $\neq \longrightarrow$ & -- \\
\hline 左端の自由度 & $\theta, \phi, \rho, S$ & $\theta, \rho, S, M_{z}$ & $S, M_{\eta}, M_{z}, M_{\omega}$ & $u, \theta, \phi, \rho$ \\
\hline 右端の境界条件 & $u=M_{\eta}=M_{z}=M_{\omega}=0$ & $u=\phi=M_{\eta}=M_{\omega}=0$ & $u=\theta=\phi=\rho=0$ & $S=M_{\eta}=M_{z}=M_{\omega}=0$ \\
\hline
\end{tabular}

$R^{\prime} \boldsymbol{V}_{n}^{R}=0$

によって表わされる20)。

\section{（2）弾性支点の境界条件式}

左端の支点において, 変形量 $u_{1}{ }^{L}, \theta_{1}{ }^{L}, \phi_{1}{ }^{L}$ および $\rho_{1}{ }^{L}$ に対応して, 次のような支点反力が生ずる。

$$
\begin{aligned}
S_{1}{ }^{L} & =-K_{u} u_{1}{ }^{L}, \quad M_{\eta 1}{ }^{L}=-K_{0} \theta_{1}{ }^{L} \\
M_{z 1}{ }^{L} & =-K_{b} \phi_{1}{ }^{L}, \quad M_{\omega 1}{ }^{L}=-K_{\omega} \rho_{1}{ }^{L}
\end{aligned}
$$

ここに， $K_{u}, K_{0}, K_{b}$ および $K_{\omega}$ はそれぞれの変形 量に対するばね定数である。

これより，左端の自由度は， $u_{1}{ }^{L}, \theta_{1}{ }^{L}, \phi_{1}{ }^{L}$ および $\rho_{1}{ }^{L}$ となり, 左端の境界マトリックス $R$ と初期ベクトル $\boldsymbol{A}_{1}{ }^{L}$ は,

$$
R=\left[\begin{array}{cccc}
1 & 0 & 0 & 0 \\
0 & 1 & 0 & 0 \\
0 & 0 & 1 & 0 \\
0 & 0 & 0 & 1 \\
-K_{u} & 0 & 0 & 0 \\
0 & -K_{0} & 0 & 0 \\
0 & 0 & -K_{b} & 0 \\
0 & 0 & 0 & -K_{\omega}
\end{array}\right], \quad A_{1}{ }^{L}=\left[\begin{array}{c}
u \\
\theta \\
\phi \\
\rho
\end{array}\right]_{1}^{L}
$$

となる。

右端においては，実際にはりは存在しないが，弾性支 点 $n$ の格点伝達マトリックス $P_{n}$ を用いて, 状態量べ クトル $\boldsymbol{V}_{n}{ }^{R}$ を弾性支点 $n$ の右側まで伝達する。

$$
\boldsymbol{V}_{n+1}{ }^{L}=P_{n} \boldsymbol{V}_{n}{ }^{R}
$$

しかるのち，右端の境界条件 $S_{n+1}{ }^{L}=0, M_{\eta n+1}{ }^{L}=0$, $M_{z n+1}{ }^{L}=0$ および $M_{\omega n+1}{ }^{L}=0$ を与える境界マトリッ クス $R^{\prime}$ を前掛けして，境界条件式，

$$
R^{\prime} V_{n+1}^{L}=0
$$

を得る。

\section{（3）一部弾性支持の場合の境界条件式}

この場合は（1）と（2）の場合の混合の左端での境界 マトリックスおよび初期ベクトルを得ることができる。 右端の境界条件は（2）の場合と同様に取り扱うことがで きる。

\section{5. 計算方法}

左端における状態量ベクトル $\boldsymbol{V}_{1}{ }^{L}$ は，格間伝達マト リックス $F_{i}(i=1,2, \cdots, n)$ と格点伝達マトリックス $P_{i}(i=1,2, \cdots, n-1)$ によって右端まで伝達され，

$$
V_{n}^{R}=F_{n} P_{n-1} F_{n-1} P_{n-2} \cdots P_{2} F_{2} P_{1} F_{1} V_{1}^{L}
$$

のように表わされ, 連続ばりの両端の状態量を関係づけ る線形方程式が得られる。

式（17）および（18）を式（20）に代入すると，

$$
R^{\prime} F_{n} P_{n-1} F_{n-1} \cdots P_{2} F_{2} P_{1} F_{1} R A_{1}{ }^{L}=0
$$

となり, 式 (21) の係数マトリックスの值を 0 と置いた $\left|R^{\prime} F_{n} P_{n-1} F_{n-1} \cdots P_{2} F_{2} P_{1} F_{1} R\right|=0$

は，はりの横倒れ座屈条件式を与える。

式（22）の数值計算に当たっては，試行錯誤法等によ ればよい。

\section{6. 数值計算例}

\section{（1）計算精度と分割数}

一様曲げを受ける単純ばりの座屈モーメントを計算す ることにより，電子計算機の精度を調べてみた。スパン 中間には荷重および拘束ばねがないので，座屈条件式 は,

$$
\left|R^{\prime} F R\right|=0
$$

となる。同じ問題をスパンを $n$ 等分し, 各分割要素に対 する格間伝達マトリックス $F_{1}, F_{2}, \cdots, F_{n}$ を用いて，

$$
\left|R^{\prime} F_{n} F_{n-1} \cdots F_{2} F_{1} R\right|=\left|R^{\prime} F R\right|=0
$$

のように座屈条件式を表わすことができる。

$n=100$ として式 (23) と式 (24) の $F$ の值を比較 した結果, 有効桁数 4 桁まで一致した。

また，図一5 に示す単純ばりに等分布荷重が作用する 場合，スパン長に対する弱軸まわりの断面 2 次半径の 比, $L / r_{y}$ (以後, 弱軸まわりの細長比という) が 300 と 100 について, 分割数を $4,8,20$ および 50 の 4 通り の計算結果を図一6 に示す。境界条件は両端で曲げおよ 
吉田・井本 :

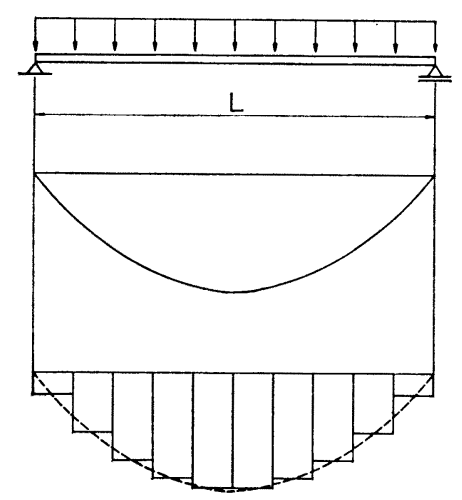

図一5＼cjkstart計算に用いる曲げモーメント分布

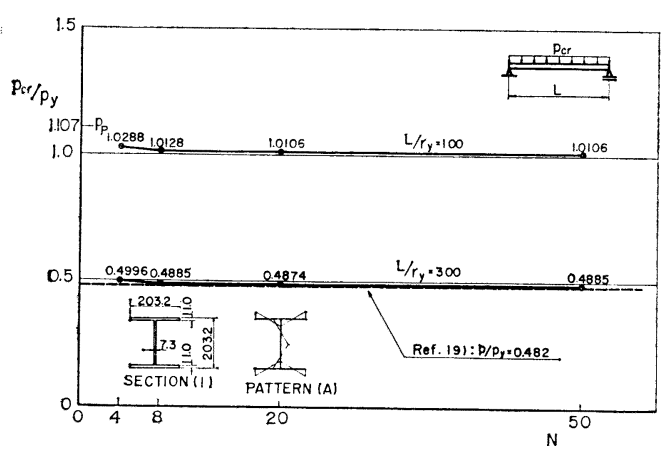

図-6 分割数と精度

びねじれに対して単純支持で, 各分割要素の曲げモーメ ントはその中点におけるものを使用した。弱軸まわりの 細長比が 300 の場合は弾性域で座屈するが, 100 の場合 は非弾性域で座屈する。いずれの場合も分割数が 8 以上 で十分な精度の解が得られる。なお, 図中の点線は, 弱 軸まわりの細長比が 300 の場合の文献 19）から得られ た理論值である。

\section{（２）２径間連続ばりの弾性座屈}

文献 7) において，アルミニウムを用いて 2 径間連続 ばりの座屈実験を行なっている。境界条件は両端および 中間支点で曲げおよびねじれに対して単純支持である。

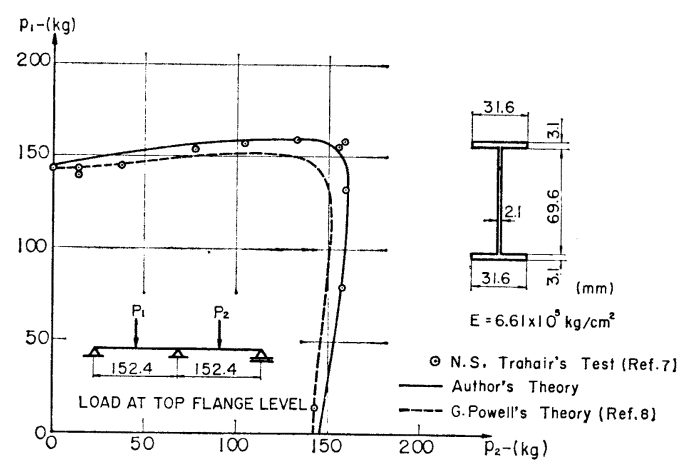

図一7 2 径間連続ばりの座屈相関関係
荷重は左右スパンの中央に集中荷重を各 1 個作用させ, これらの荷重の相関関係を実験的に 調べている。図一7 の実線は同じ境界条件と材料の定数を用いて計算した值 を, 黒丸は文献 7) の実験值を, 図中点線は文献 8）の 計算値を示している。

\section{（3）種々の拘束条件のあるはりの弾性座屈}

文献 8）において 剛性法を用いて計算している図一8 (a)に示すはりの横倒れ座屈解析を行なら。断面は図一 8（c）に示す 3 種類のものが用いられており，荷重の作 用位置は (1)〜(2) の間が上フランジに, (4)および (5) の 荷重は下フランジにそれぞれ作用しているものとする。 拘束条件としては，(1) と (6) で横変位と衫じりが剛支持 されており，(2) では上フランジの横変位が剛支持され， (4)および (5) で下フランジの横変位に対して, ばね定数 が $1786 \mathrm{~kg} / \mathrm{cm}$ のばねで弾性支持され，(7)でねじりが 剛支持されている。(2) では上フランジの横変位 $\bar{u}$ が 0 となるから，

$$
\vec{u}=u-\phi h_{u}=0
$$

を用いて初めの未知量 $S$ を消去して, 新しい未知量 $S^{\prime}$ を導入する。(4)および (5) では弾性ばね $K_{u}$ と荷重の 高さ $h_{0}$ に対して次の飛躍量が生ずる。

$$
\begin{aligned}
& S=-K_{u} u+K_{u} h_{l} \phi \\
& M_{z}=-K_{u} h_{l} u+\left(P h_{0}+K_{u} h_{l}{ }^{2}\right) \phi
\end{aligned}
$$

ここに $h_{u}$ および $h_{l}$ はせん断中心から上フランジお よび下フランジまでの距離である。6 においては横変 位 $u$ と㸚り角 $\phi$ が 0 といら条件を用いて未知量 $S^{\prime}$
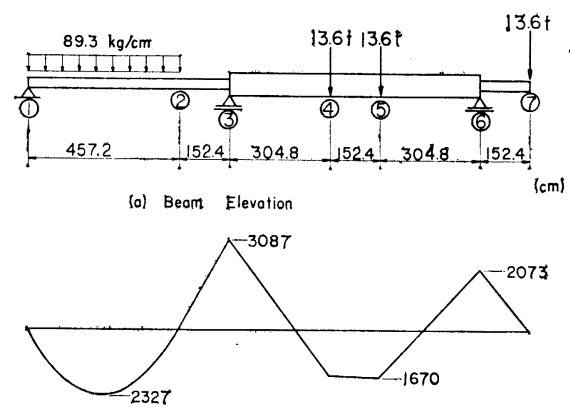

(b) Bending Momenf Diagram $(t-\mathrm{cm})$
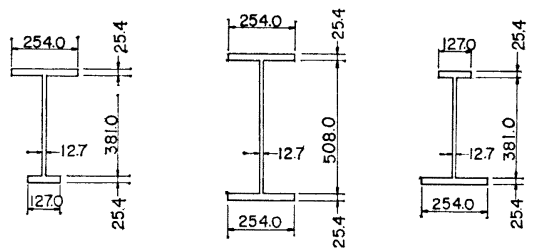

$$
\text { (1) (3) }
$$$$
\text { (3) } \sim \text { (6) }
$$$$
\text { () } \sim 7
$$

(c) Cross Sectional Diagram $5 \mathrm{mml}$ 
および $M_{z}$ を消去して, 新しい未知量 $S^{\prime \prime}$ と $M_{z}^{\prime}$ を導 入する。

数值計算にあたっては，第 1 スパンを 80 等分, 第 2 スパンを 100 等分，張出し部を 20 等分に分割し，(2)， (4),(5) および (6) の点で上述の格点伝達マトリックスを 用いて計算を行なった。

文献 8) による座屈安全率は 2.13 であるが, 本理論 による計算值は 1.85 である。この相違は本計算におい ては，分割数を十分多くとっていることが考えられる。

\section{7. 非弾性域での横倒れ座屆の計算例および 考察}

\section{（1）非弾性域での断面の曲げおよびねじりに関する 係数}

$\mathrm{H}$ 形断面のフランジ抒よびウェブを微小長方形要素に 分割することによって，任意の残留応力分布の影響を考 慮した曲げおよびねじりに関する断面の諸係数の数值計 算法が文献 16) に示されている。

図一9 12 は代表的な 4 つの $\mathrm{H}$ 形断面（表一3）の弱 軸まわりの曲げ剛性, 曲げねじり剛性, 曲げによる垂直 応力および残留応力によって生ずるせん断中心まわりの 付加トルクおよびせん断中心の位置の変化を示したもの である。実線は図一1 (a) に示す残留応力 Pattern (A) に対するものであり，点線は Pattern (B) に対するも のである。

\section{表一3 計算に用いる $\mathrm{H}$ 形断面}

\begin{tabular}{|c|c|c|c|c|c|c|}
\hline Section No. & $\begin{array}{l}\text { Depth } \\
\text { (0) } \\
\text { (a) }\end{array}$ & \begin{tabular}{|c|}
$\begin{array}{c}\text { Flonge } \\
\text { Width } \\
\text { (B) }\end{array}$ \\
\end{tabular} & \begin{tabular}{|l} 
Flange \\
Thickness \\
(T)
\end{tabular} & $\begin{array}{l}\text { Web } \\
\text { Thickness } \\
\text { (W) }\end{array}$ & Remarks & 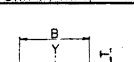 \\
\hline 1 & 203.2 & 203.2 & 11.0 & 7.3 & $8 w=31$ & 7 \\
\hline 2 & 683.5 & 253.7 & 19.0 & 12.4 & $27 V F 94$ & $-x 0$ \\
\hline 3 & 374.7 & 393.7 & 27.0 & 17.3 & $14 W=142$ & $r_{i}$ \\
\hline 4 & 412.8 & 405.0 & $46 . i$ & 28.6 & $14 W=24 E$ & $\frac{y}{B}-1$ \\
\hline
\end{tabular}

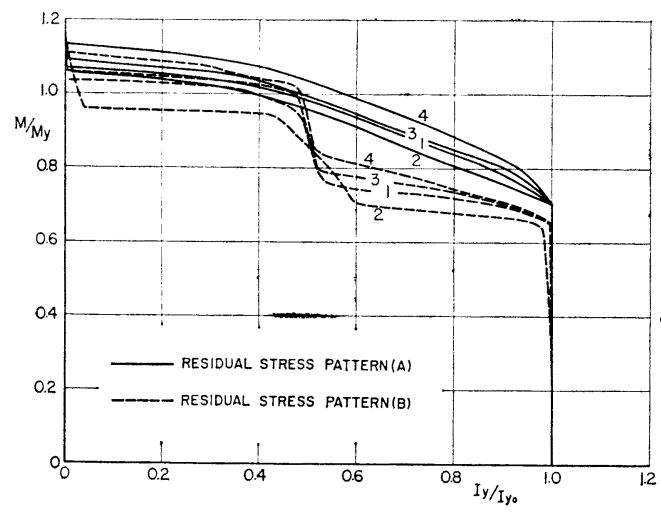

図一9 非弾性域での弱軸まわりの曲げ剛性
数値計算においては，仮定した荷重による各分割要素 の中点の曲げモーメントを計算し，その曲げモーメント に対する断面の係数を用いて座屈条件式 (22) の值を計 算し, 試行錯誤により座屈荷重を決定することができ る。以下に単純ばりの非弹性座屈について, 境界条件お よび荷重条件を変化させた場合の計算結果を示す。

\section{（2）荷重条件の影響}

以下，表一3 の断面 1 の単純ばりを用いて，荷重条件

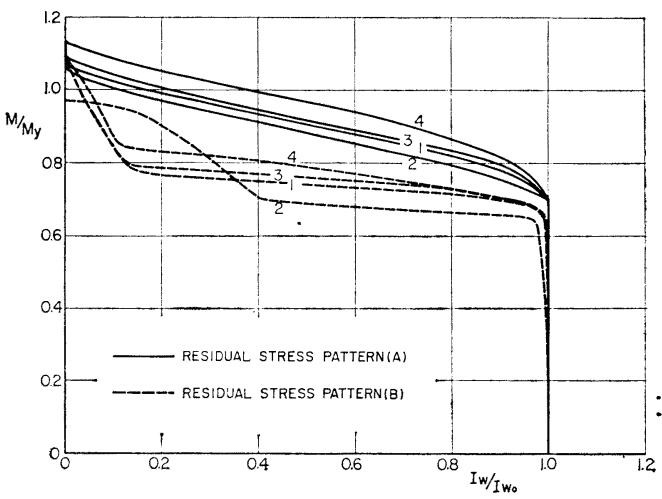

図一10 非弾性域での曲げねじり剛性

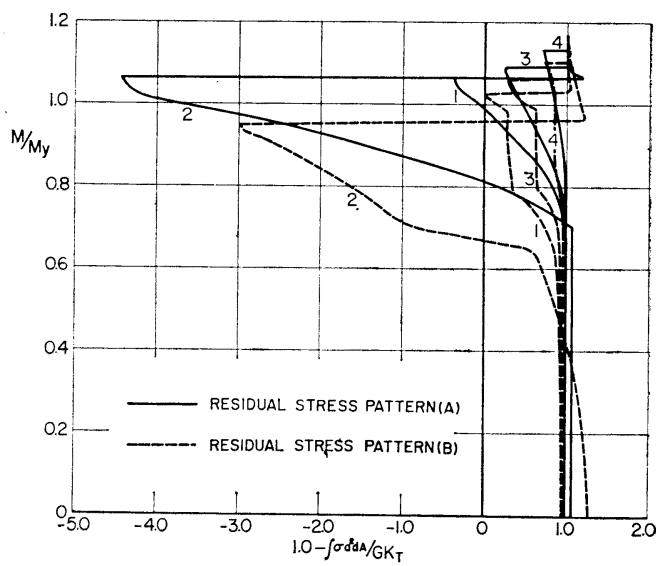

図一11 非弾性域での付加ねじりモーメントに関する係数

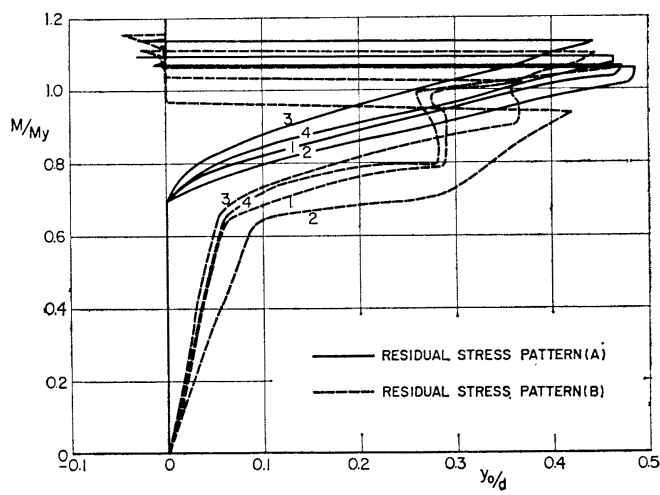

図一12 非弾性域でのせん断中心 
がはりの横倒れ座屈におよぼす影響について，2〜3の 考察を行なう。境界条件は両端で曲げおよびねじれに関 して単純支持である。

a) 荷重の種類

図一13 は，単純ばりの中央に 1 個の集中荷重が作用 する場合，等分布荷重が作用する場合および一様曲げが 作用する場合の座屈曲線を示している。実線は残留応力 分布の Pattern (A) を, 点線は Pattern (B) のもの を示している。弱軸まわりの細長比が 100 以上では, 一 様曲げが作用する場合の座屈モーメントは, 集中荷重が 1 個作用する場合のスパン中央の曲げモーメントの約 80\%であり，この割合は弾性域および非弾性域を通じ て, ほぼ一定である。一般の構造物に作用する荷重によ る曲げモーメント分布は, 1 点集中荷重によるものと, 一様曲げを受ける場合の中間にある。

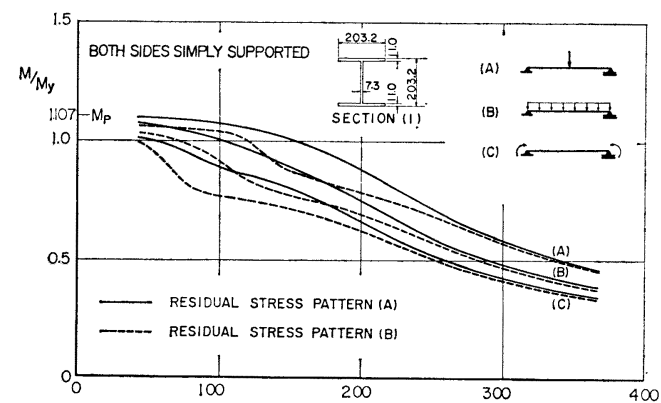

図一13 各種荷重による単純ばりの非弾性横倒れ座屈

弱軸まわりの細長比が大きい範囲では, 残留応力分布 の Pattern (B) の座屈モーメントは, Pattern (A) の ものより数\%小さい程度であるが， 1 点集中荷重の場合 は, 細長比が 150〜200 の範囲で, 一様曲げの場合は 70 150 の範囲で最大 $15 \%$ 低下する。これは残留応力 分布の Pattern (B) の場合は, 残留応力がない場合の 降伏曲げモーメントの 0.7 倍付近で，上フランジが， 両端から急激に降伏することによっている。

b) 荷重の作用点

図一14 および 15 は，1個の集中荷重がスパン中央に

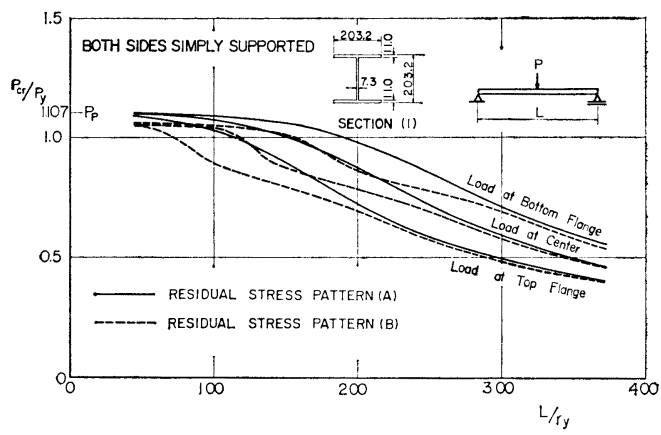

図一14 集中荷重による単純ばりの非弾性横倒れ座届 （荷重作用点の影響）

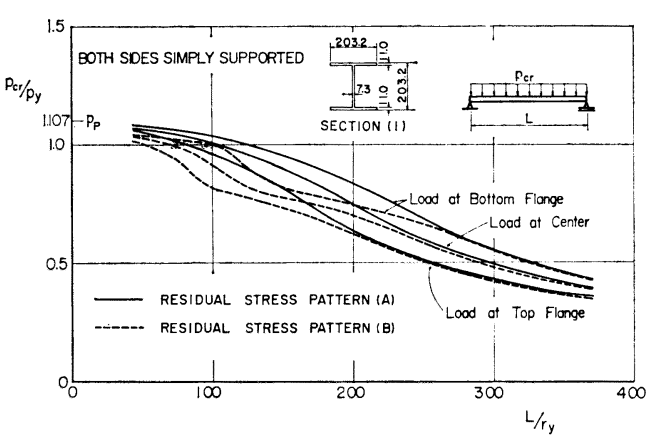

図一15 等分布荷重による単純ばりの非弾性 横倒れ座屈 (荷重作用点の影邡)

作用する場合と等分布荷重が作用する場合の荷重作用点 の相違による影響を示している。それぞれ，荷重が上フ ランジに作用する場合，断面の中央に作用する場合およ び下フランジに作用する場合について示してある。残留 応力分布を無視したこれらの值は, 弾性域で文献 19)の 值と一致する。荷重作用点の相違による影響は非弾性域 においても弾性域とほぼ同じであるが, 細長比の減少と ともに，その影響は減少している。

c）モーメント勾配

図一16には，両端で不等曲げを受ける単純ばりの横 倒れ座屈の座屈曲線を示している。残留応力分布は, Pattern（A）のものである。右端に作用する曲げモー メントが左端に作用する 曲げモーメントの $q$ 倍の 場合 について, $q$ を 1.0 から 0.2 間隔で -1.0 まで変化 させており, モーメント勾配と座屈長さの関係を, 弾性 域のみならず非弾性域においても知ることができる。

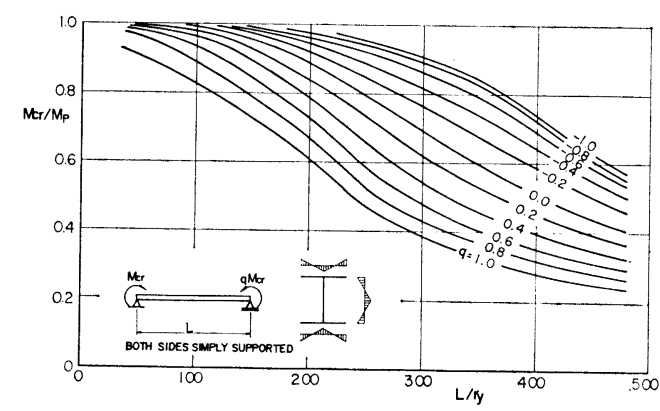

図一16 不等曲げを受ける単純ばりの非弾性横倒れ座屈

図一17 は $q=1.0,0,-1.0$ の 3 つの場合に，等分布 荷重のみの座屈荷重の $\alpha=0.2$ および 0.4 倍の等分布 荷重が作用する場合の座屈曲線を示している。実線は残 留応力分布の Pattern (A) を, 点線は Pattern (B) を 示している。 $q=-1.0$ の場合, 残留応力分布の Pattern (A) の場合では細長比の 比較的大きいところで座屈モ 一メントの低下が著しいが, Pattern (B) では細長比の 200 付近で低下する。また $q=1.0$ では残留応力分布 の Pattern (A) および (B) とも, 細長比の 100 付近 


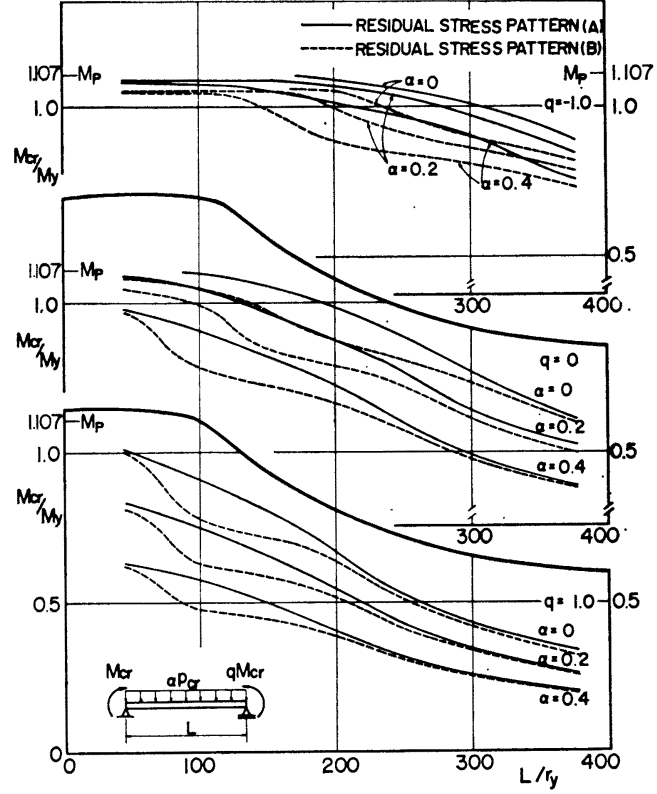

図一17 不等曲げと等分布荷重を受ける非弾性横倒れ座屈

で，座屈モーメントが著しく低下し，その低下の割合は $q=-1.0$ の場合の 2 倍に達する。

\section{（3）境界条件の影響}

表一3 の断面 1 の単純ばりに一様曲げを受ける場合の 横倒れ座屈強度を, 表一4 に示す各種の境界条件につい て計算を行なったのが図一18 および 19 である。図一18 は残留応力分布の Pattern (A) の場合を, 図一19 は Pattern（B）の場合を示している。

当然のことであるが，曲げおよびねじりに対して単純 支持の場合が最も座屈モーメントが小さく, 両端が固定 の場合が最も大きい。また, 計算に用いた断面では, 曲 げを固定した場合が，ねじりを固定した場合より大きい 座屈モーメントを与えることがわかる。

表一4 境界条 件

\begin{tabular}{|c|c|c|}
\hline & 左端の境界条件 & 右端の境界条件 \\
\hline (1) & $u=u^{\prime \prime}=\Phi=\Phi^{\prime \prime}=0$ & $u=u^{\prime \prime}=\Phi=\Phi^{\prime \prime}=0$ \\
\hline (2) & $\boldsymbol{u}=\boldsymbol{u}^{\prime \prime}=\Phi=\Phi^{\prime \prime}=0$ & $u=u^{\prime \prime}=\Phi=\Phi^{\prime}=0$ \\
\hline (3) & $u=u^{\prime \prime}=\emptyset=\Phi^{\prime \prime}=0$ & $u=u^{\prime}=\Phi=\Phi^{\prime \prime}=0$ \\
\hline (4) & $\boldsymbol{u}=\boldsymbol{u}^{\prime \prime}=\emptyset=\Phi^{\prime \prime}=0$ & $\boldsymbol{u}=\boldsymbol{u}^{\prime}=\emptyset=\Phi^{\prime}=0$ \\
\hline (5) & $u=u^{\prime \prime}=\Phi=\Phi^{\prime}=0$ & $u=u^{\prime \prime}=\emptyset=\Phi^{\prime}=0$ \\
\hline (6) & $u=u^{\prime}=\Phi=\Phi^{\prime \prime}=0$ & $u=u^{\prime}=\Phi=\Phi^{\prime}=0$ \\
\hline (7) & $u=u^{\prime}=\emptyset=\Phi^{\prime}=0$ & $u=u^{\prime}=\Phi^{\prime}=\Phi^{\prime}=0$ \\
\hline (8) & $u=u^{\prime}=\emptyset=\Phi^{\prime \prime}=0$ & $\boldsymbol{\varepsilon} i=\boldsymbol{u}^{\prime}=\emptyset=\Phi^{\prime \prime}=0$ \\
\hline (9) & $u=u^{\prime}=\emptyset=0$ & $u=u^{\prime \prime}=\Phi=\Phi^{\prime}=0$ \\
\hline
\end{tabular}

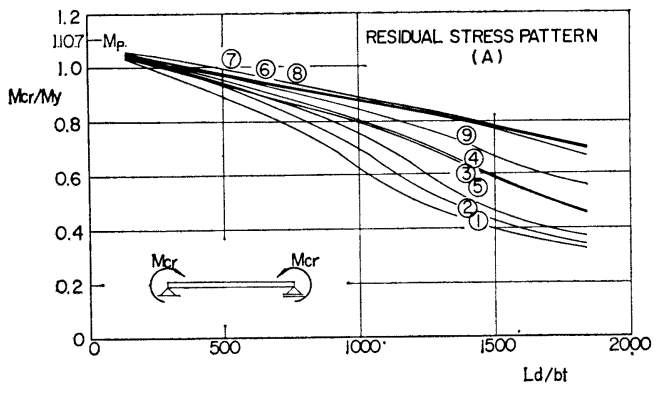

図一18各種境界条件での等曲げを受ける単純ばりの 非弾性横倒れ座屈（残留応力 PATTERN(A)）

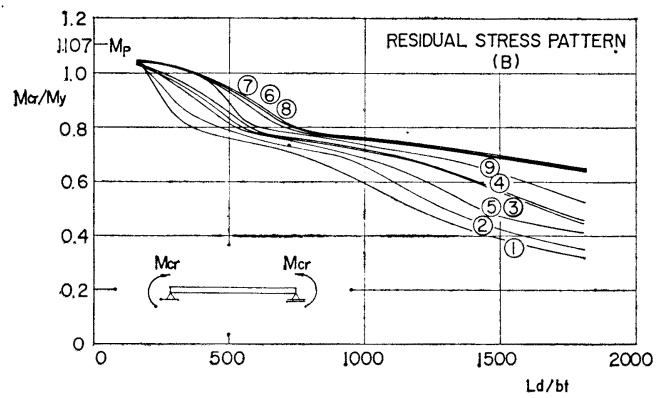

図一19 各種境界条件での等曲げを受ける単純ばりの 非弾性横倒れ座屈（残留応力 PATTERN (B))

\section{（4）断面の影響}

表一3 に示す断面 1 と断面 2 を用いて, 座屈強度にお よぼす断面形状の影響について検討してみた。断面 1 は フランジ幅が断面の高さに等しく, 横倒れ座屈がおこり にくい断面であり, 断面 2 はフランジ幅が断面の高さの 2.8 分の 1 で, 横倒れ座屈しやすい断面である。

文献 10)において, 曲げおよびねじりに対して単純支 持の一様曲げによるはりの座屈モーメントは, 横軸に $L d / b t$ をとることにより，ほぼ断面に関係なく表わされ ることが示されている。

本研究においては, 同様の検討を表一4の9 種類の境 界条件について, 残留応力分布の Pattern (A) および

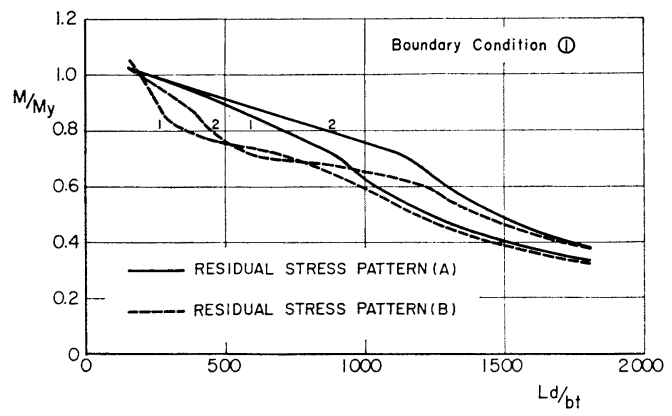

図一20等曲げを受ける単純ばりの非弾性横倒れ坐屈の 断面の影響（両端が曲げおよびねじりに対して 単純支持) 


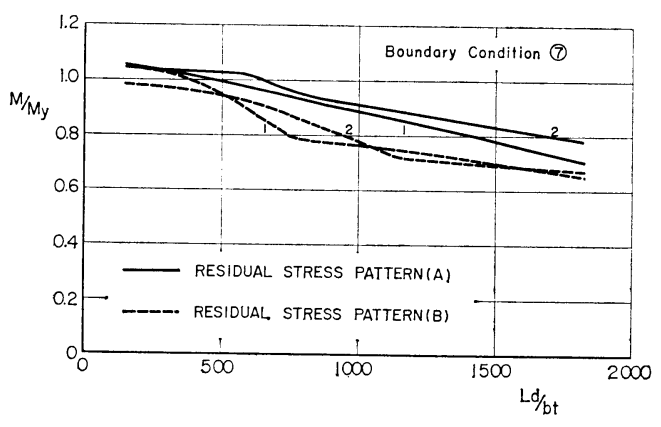

図一21等曲げを受ける単純ばりの非弾性横倒れ座屈の 断面の影響（両端が曲げおよびねじりに対して 固定支持）

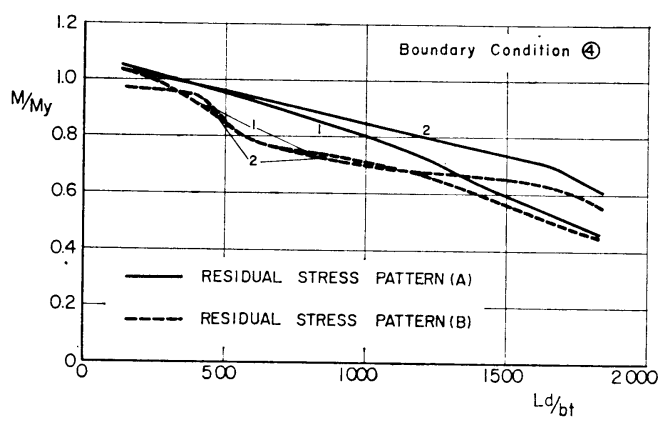

図一22 等曲げを受ける単純ばりの非弾性横倒れ座屈の 断面の影響（曲げおよびねじりに対して1端が 単純支持, 他端が固定支持)

(B) の場合に対して検討してみた。

図一20 は文献 10）に見られる両端が曲げおよびねじ りに対して単純支持の場合であり, 図一20 は両端固定 の場合を, 図一22 は 1 端が単純支持で他端が固定の場 合を示している。両端固定の場合は断面による影響は比 較的小さいが，1端が単純支持で他端が固定の場合は, かなり大きい差が見られる。その他の境界条件の場合は この中間にある。

\section{8. 結論}

本研究においては, はりの横倒れ座屈を伝達マトリッ クスを用いて解析した。はりの分割要素間では曲げモー メントが一定であるとし, 格間伝達マトリックスを導 き，また，支点およびスパン中間で種々の拘束を考慮し た格点伝達マトリックスを用いて任意の荷重条件, 拘束 条件および境界条件を有するはりの横倒れ座屈の解析法 を示した。

計算例として 3 つの支点で横変位およびねじれに対し て単純支持である 2 径間連続ばりおよび各種の拘束をう ける 2 径間連続ばりの横倒れ座屈の解析例を示した。

また, 非弾性横倒れ座屈の計算手法を示した。まず, はり断面の非弾性域での各種の係数を計算し, これらの
值を用いて任意の荷重条件および境界条件に対する座屈 解析法を示し, 単純ばりの非弾性横倒れ座屈強度に関す る次の諸点について検討を行なった。

1）作用荷重の種類による影響

2）作用荷重位置の影響

3）境界条件の影響

4）モーメント勾配の影響

5）残留応力の影響

6）断面の影響

本研究により，任意の境界条件および拘束条件を有す るはりの横倒れ座屈解析が容易になったと考えられる。 また，これまでモーメント勾配を有するはりの非弾性横 倒れ座屈解析が困難であるとされていたが，容易に解析

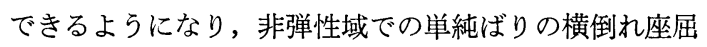
に関する若干の資料が示された。

なお，本方法を用いることにより，各種の拘束条件を 有する連続ばり, 変断面はり等の非弾性横倒れ座屈の解 析も容易である。

本研究に当っては名古屋大学 成岡昌夫教授, 福本唀 士助教授にお世話になった。

なお，使用した電子計算機は金沢大学の FACOM 230-35 である。

\section{記 号}

$A^{L}$ : 左端の自由度から成る初期ベクトル

$\boldsymbol{a}:$ 倸数ベクトル

$b:$ フランジ幅

$d:$ 断面の高さ

$E I_{\omega},\left(E I_{\omega 0}\right)$ : 曲げねじり剛性（弾性域での曲げねじ り剛性)

$E I_{y},\left(E I_{y 0}\right):$ 弱軸まわりの曲げ岡性（弾性域での曲 げ剛性)

$F_{i}:$ 格間伝達マトリックス

$G K_{T}:$ St. Venant のねじり剛性

$h_{u}, h_{l}:$ せん断中心から上下フランジまでの距離

$h_{0}:$ せん断中心から荷重作用点までの距離

$I_{x}: x$ 軸まわりの断面 2 次モーメント

$K_{b i}$ : 点 $i$ におけるねじり角に対する拘束ばね定数

$K_{0 i}$ : 点 $i$ における横たわみ角に対する拘束ばね定数

$K_{u i}$ : 点 $i$ における横変位に対する拘束ばね定数

$K_{\omega i}:$ 点 $i$ におけるそりに対する拘束ばね定数

$L:$ スパン長

$l:$ 格間長

$L / r_{y}:$ 弱軸まわりの細長比

$M:$ 作用曲げモーメント

$M_{c r}$ : 座屈曲げモーメント

$M_{0}$ : はり要素の曲げモーメント

$M_{p}$ : 全塑性曲げモーメント 
$M_{y}$ : 残留応力のないはりの弾性限界曲げモーメント

$M_{z}:$ ねじりモーメント

$M_{\omega}:$ バイモーメント

$M_{\eta}: y$ 軸まわりの曲げモーメント

$n:$ 分割数

$P:$ 集中荷重強度

$P_{c r}:$ 集中荷重による座屈強度

$P_{i}:$ 格点伝達マトリックス

$p:$ 等分布荷重強度

$p_{c r}:$ 等分布荷重による座屈強度

$p_{y}$ : 残留応力のないはりの等分布荷重による弾性限 界強度

$q$ : 右端に作用する曲げモーメントと左端に作用す る曲げモーメントの比

$R:$ 左端の境界マトリックス

$R^{\prime}:$ 右端の境界マトリックス

$S:$ せん断力

$S^{\prime}, S^{\prime \prime}$ : せん断力の飛躍量

\section{$t:$ フランジ厚さ}

$u:$ せん断中心の横変位

$\vec{u}:$ 上フランジの横変位

$\boldsymbol{V}_{i}{ }^{L}, \boldsymbol{V}_{i}{ }^{R}$ : 格間 $i$ の左側および右側の状態量ベクトル w : ウェブ厚さ

$\alpha$ : 等分布荷重の等分布荷重のみによる座屈強度に 対する比

$\theta:$ 横たわみ角

$\rho:$ ねじり率

$\phi:$ せん断中心まわりのねじり角

\section{参考 文 献}

1）福本唀士・久保全弘：横構・対傾構をもつ桁の横倒れ座 屈強度，土木学会論文報告集，第 196 号， pp. 19 28, 1971 年 12 月

2) 福本唀士 -久保全弘 : 横倒れ 座屈強度と 横補剛効果, JSSC, Vol. 7, No. 71, pp. 11 22, 1971 年 11 月

3）吉田 博 - 西田 進: ねじり拘束のあるはりの横倒れ座 屈強度, 第 25 回土木学会年次学術講演会概要集, pp. 53 $\sim 54,1970$ 年 11 月

4) Schmidt, L.C. : Restraints Against Elastic Lateral Buckling, Proc. of ASCE, Vol. 91, No. EM 6, pp. 1 10, Dec., 1965.

5) Taylor, A.C. and Ojalvo, M. : Torsional Restraint of
Lateral Buckling, Proc. of ASCE, Vol. 92, No. ST 2, pp. 115 129, April, 1966.

6) Hartman, A.J. : Elastic Lateral Buckling of Continuous Beams, Proc. of ASCE, Vol. 93, No. ST 4, pp. 11 26, August, 1967.

7) Trahair, N.S. : Elastic Stability of Continuous Beams, Proc. of ASCE, Vol. 95, No. ST5, pp. 1295 1311, June, 1969.

8) Powell, G. and Klinger, R. : Elastic Lateral Buckling of Steel Beams, Proc. of ASCE, Vol. 96, No. ST 9, pp. 1919 1932, Sept., 1970.

9) Baker, J., Horne, M.R. and Heyman, J. : The Steel Skelton, Vol. 2, Plastic Behaviour and Design, Cambridge Univ. Press, 1965.

10) Galambos, T.V. : Inelastic Lateral Buckling of Beams, Proc. of ASCE, Vol. 89, No. ST 5, pp. 217 242, Oct., 1963.

11) Fukumoto, Y. and Galambos, T.V. : Inelastic LateralTorsional Buckling of Beam-Columns, Proc. of ASCE, Vol. 92, No. ST 2, pp. 41 61, April, 1966.

12) Galambos, T.V., Adams, P.F. and Fukumoto, Y. : Further Study on the Lateral-Torsional Buckling of Steel Beam-Columns, Welding Research Council Bulletin, No. 115, pp. 1 11, July, 1966.

13) Hartman, A.J. : Inelastic Flexual-Torsional Buckling, Proc. of ASCE, Vol. 97, No. EM. 4, pp. 1103 1117, August, 1971.

14) Unger, B. : Elastisches Kippen von beliebig gelagerten und aufgehängten Burchlaufträgern mit einfach-symmetrischem, in Trägerachse veränderlichem Querschnitt und einer Abwandlungdes Reduktinsverfahrens als Lösungsmethode Dissertation, Technischen Hochschule Darmstadt, 1969.

15) Sakimoto, T. and Namita, Y. : Out of Plane Buckling of Solid Rib Arches Braced with Transverse Bars, Proc. of JSCE, No. 191, pp. 109 116, July, 1971.

16) Yoshida, H. and Nishida, S. : Lateral-Torsional Properties of Wide-Flange Sections with Residual Stresses, Memoirs of the Faculty of Technology, Kanazawa University, Vol. 6, No. 3, pp. 13 23, 1971.

17）福本唀士・西野文雄訳 (Galambos 著)：鋼構造部材と骨 組一強度と設計, 丸善, 1970 .

18) Timoshenko, S.P. and Gere, J.M. : Theory of Elastic Stability, McGraw-Hill, Second Edition, 1961.

19) Bleich, F. : Buckling Strength of Metal Structures, McGraw-Hill, 1952.

20）成岡昌夫・遠田良喜 : 伝達マトリックス法, コンピュー ターによる構造工学講座, 培風館, 1970 .

21) Pestel, E.C. and Leckie, F.A. : Matrix Methods in Elastomechanics, McGraw-Hill, 1963.

\section{【付 録】}

$F_{i}=\left[\begin{array}{ccc}1 & l & 0 \\ 0 & 1 & 0 \\ 0 & 0 & 1 \\ 0 & 0 & 0\end{array}\right.$

$$
\begin{gathered}
-\frac{1}{E I_{y} A_{2}^{2}}\left(\frac{D_{9}}{A_{1} A_{2}}+A_{3} l\right) \\
-\frac{1}{E I_{y} A_{2}{ }^{2}}\left(\frac{D_{8}}{A_{1}}+A_{3}\right) \\
\frac{1}{M_{0}}\left(\frac{D_{6}}{A_{1} A_{2}}-l\right) \\
\frac{1}{M_{0}}\left(\frac{D_{5}}{A_{1}}-1\right)
\end{gathered}
$$




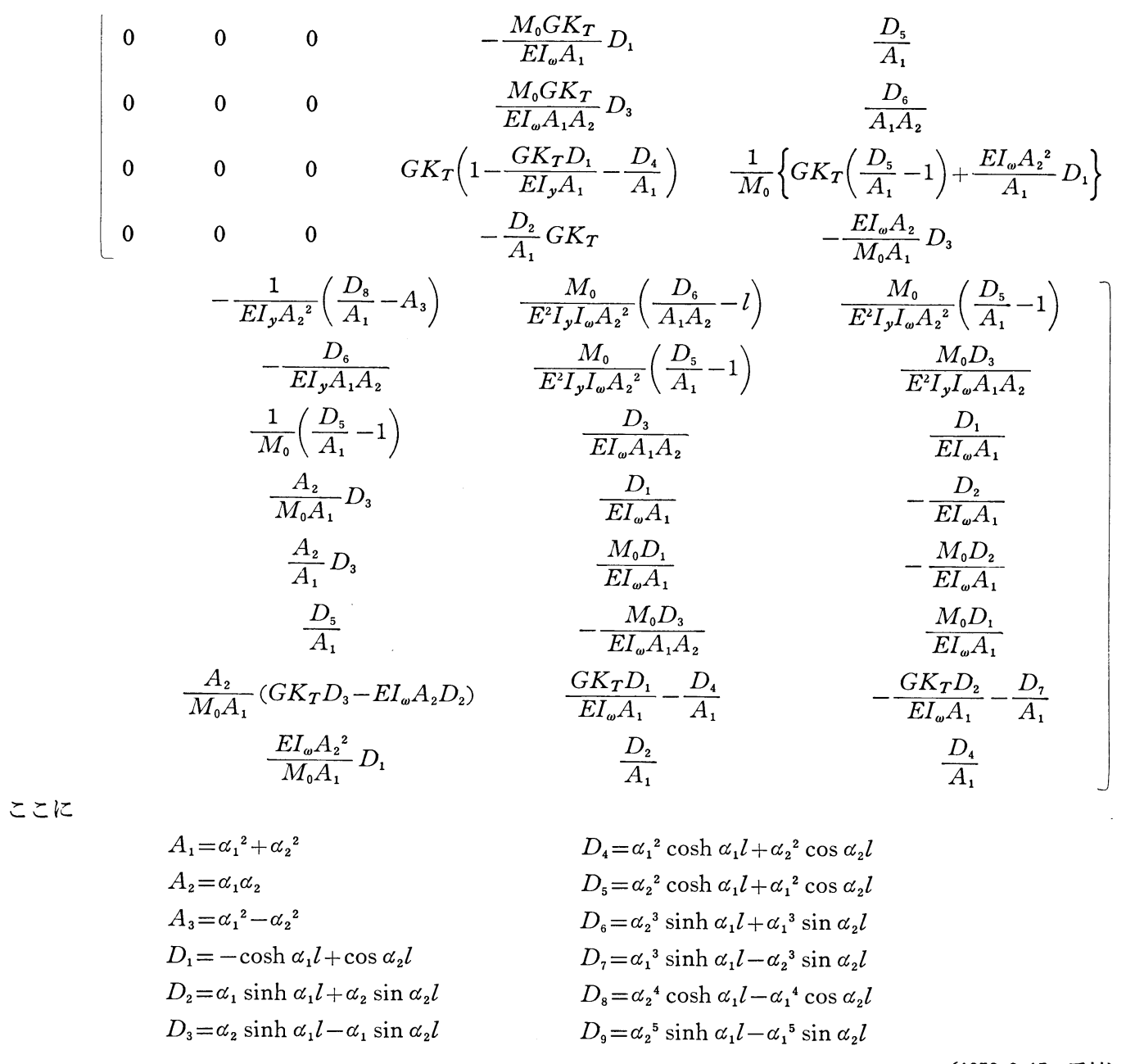

